HELMINTHOLOGIA, 54, 2: 132 - 144, 2017

\title{
Parasitic infections of anurans from a freshwater creek community in Delta State, Niger Delta of Nigeria
}

\author{
M. S. O. AISIEN ${ }^{1 *}$, A. P. UGBOMEH², A. O. AWHARITOMA ${ }^{1}$
}

'Laboratory of Parasitology Research, Department of Animal and Environmental Biology, Faculty of Life Sciences, University of Benin, P.M.B. 1154, Benin City, Nigeria; ${ }^{2}$ Department of Applied and Environmental Biology, Faculty of Science, Rivers State University of Science and Technology, Nkpolu-Oroworukwo, Port Harcourt, Nigeria

*E-mail: aisien@uniben.edu

\section{Article info}

Received December 3, 2015 Accepted March 14, 2017

\begin{abstract}
Summary
The parasitic infections of 125 anurans belonging to 13 taxa from Ase community in Delta State in the Niger Delta of Nigeria was investigated. An overall prevalence of $77.6 \%$ was recorded and the 32 parasites recovered included one pentastomid, four cestode, four monogenean, ten digenean and thirteen nematode taxa. Among the anurans examined, Ptychadena bibroni harboured the highest number of parasites. Most of the parasites encountered were adults but some occurred as larvae, which either used the amphibians as intermediate or transport hosts. Hylarana galamensis is considered an accidental host for the larval brachylaimid trematode and, a new host record for the larval strigeiod while Polystoma galamensis infection of this frog is made for the first time outside the savannah biotope. Hymenochirus sp. is a new host record for Progonimodiscus colubrifer. Two Foleyellides spp., one occurring in Hyperolius concolor, Afrixalus fulvovitattus and Sclerophys regularis and the other in $\mathrm{H}$. galamensis occur in the study area.

Keywords: Parasitic infections; anurans; Ase creek; Niger Delta; Nigeria
\end{abstract}

\section{Introduction}

The vegetation zones of Nigeria include the mangrove and fresh water swamps of the Niger Delta, followed by the rainforest, derived savannah, guinea savannah, montane forest and the sahel savannah of the extreme north. Investigations of the parasites of amphibians in Nigeria have mostly been undertaken in the forest and savannah biotopes of the country (Thurston, 1967, 1970; Avery, 1971; Aisien and Du Preez, 2009; Aisien et al., 2001, 2003, 2004a, 2009, 2011, 2015; Imasuen and Aisien, 2012, 2015; Imasuen et al., 2012a). Investigations have also been carried out on pipid anurans (Hymenochirus curtipes and Xenopus tropicalis) obtained from the Lagos (coastal) area of the country (Jackson and Tinsley, 1995, 1998a, b).

Some information is available on the parasites of anurans from the freshwater swamp of the Niger Delta, Nigeria (Oddo, 2008) but none from the freshwater creeks of this region. Recent visits to Ase, a community located on the shores of Ase Creek in Delta State of Nigeria, afforded us the opportunity to collect and examine anurans from the locality for their parasitic infections. In this paper we report on the diverse parasitic infections of these frogs, some of which are being reported for the first time in Nigeria while others represent new geographical records for the country.

\section{Materials and Methods}

Study area

The amphibians investigated were collected from Ase town $\left(05.17^{\circ} \mathrm{N} ; 06.18^{\circ} \mathrm{E}\right)$, Delta State in the Niger Delta of Nigeria between July and September, 2014 and then in the months of June and August in 2015. The town lies on the shores of the Ase Creek on the course of Ase River, which is a tributary of the Forcados

\footnotetext{
$\bar{*}$ - corresponding author
} 


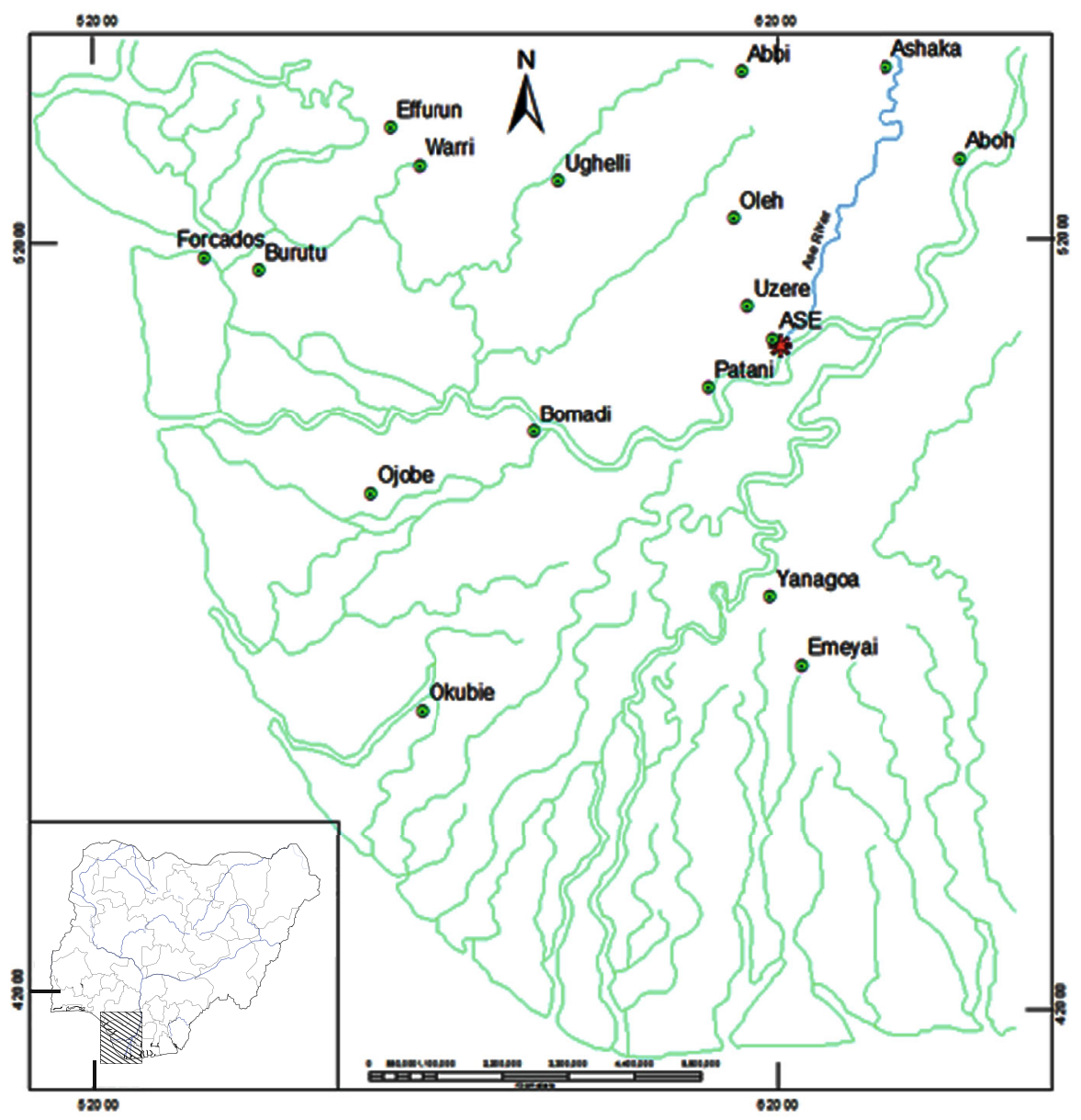

Fig. 1. Map of the Niger Delta, Nigeria showing the location of Ase

River, the western branch of River Niger in the Delta of southern Nigeria (Fig 1). The climate of the area is tropical and it is divided into the rainy (February to October) and dry (November to January) seasons, with intermittent rains in the month of December. During the later part of the rainy season (September and October), the area gets inundated and aquatic species of both plants and animals are carried ashore with some getting stranded when the water recedes.

\section{Amphibians}

All 13 amphibian species (except Hymenochirus sp.) were collected by hand at night using the Visual Acoustic Encounter Survey (VAES) method (Crump and Scott, 1994). Specimens of Hymenochirus sp. were caught after the pond harbouring them was drained. The anurans were transported to the laboratory and specimens collected were identified using the protocols of Schiøtz $(1963,1967,1999)$ and Roedel (2000). The anurans were euthanized by immersion in Benzocaine solution followed by post-mortem examination. The gastro-intestinal tract (oesophagus/stomach, small intestine, large intestine/rectum), lungs, uri- nary bladder, liver/gall bladder and the body cavity were examined for parasites. Flatworms (cestodes, monogeneans and digeneans) were flattened under cover slip pressure on microscope slides and fixed with $5 \%$ formol-saline. Prior to staining, the specimens were washed free of the fixative and then stained overnight in a dilute solution of acetocarmine. The parasites were dehydrated in alcohol series, cleared in xylene and permanent mounts made in Canada balsam. Nematodes were fixed and preserved in $70 \%$ alcohol and were cleared for examination in lactophenol. Cysts of helminth parasites were isolated, crushed under cover slip and the enclosed parasitic group identified. Parasites were identified using appropriate keys (Yamaguti, 1971; Prudhoe and Bray, 1982; Khalil et al., 1994) and either drawn using a drawing tube attached to a Nikon Alpa-Phot-2-microscope or photomicrographs taken with a Coolpix Digital Camera (3.34 Megapixels) attached to the same microscope.

Frog specimens investigated in the study have been deposited in the Amphibian Collection of Prof. A.B.M. Egborge Museum, University of Benin, Benin City, Nigeria. Parasite specimens deposited at the Natural History Museum, London and their NHMUK 
Table 1. Helminth parasites of amphibians from Ase creek, Delta State of Nigeria.

\begin{tabular}{ll}
\hline Parasite & Habitat \\
\hline Pentastomida & \\
Raillietiella sp. & Lungs
\end{tabular}

\section{Cestoda}

Cylindrotaenia jaegerskioeldi

Small intestine

Cephalochlamys compactus

Small intestine

Larval Proteocephalid

Body cavity

Proteocephalus sp.

Small intestine

\section{Monogenea}

Polystoma aeschlimanni

Urinary bladder

Polystoma baeri

Urinary bladder

Polystoma galamensis

Urinary bladder

Polystoma pricei

Urinary bladder

\section{Digenea}

Diplodiscus fischthalicus

Large intestine/rectum

Ganeo africana

Small intestine

Metahaematoloechus exoterorchis

Lungs

Metahaematoloechus micrurus

Lungs

Mesocoelium monodi

Small intestine

Mesocoelium sp.

Small intestine

Ophidiscus sp.

Large intestine/rectum

Brachylaimid (metacercariae)

Large intestine/rectum

Progonimodiscus colubrifer

Large intestine/rectum

Strigeoid larva

Small intestine

\section{Nematoda}

Amplicaecum sp.

Small intestine

Ascaridoid larva I

Body cavity

Ascaridoid larva II

Stomach mucosa

Batrachocamallanus siluranae

Oesophagus/stomach

Capillaria sp.

Small intestine

Cosmocerca ornata

Large intestine/rectum

Folleyelides sp. I

Body cavity

Folleyelides sp. II

Body cavity

Rhabdias africanus

Lungs

Rhabdias sp. I

Lungs

Rhabdias sp. II

Lungs

Rhabdias sp. III

Lungs

Oswaldocruzia hoepplii 

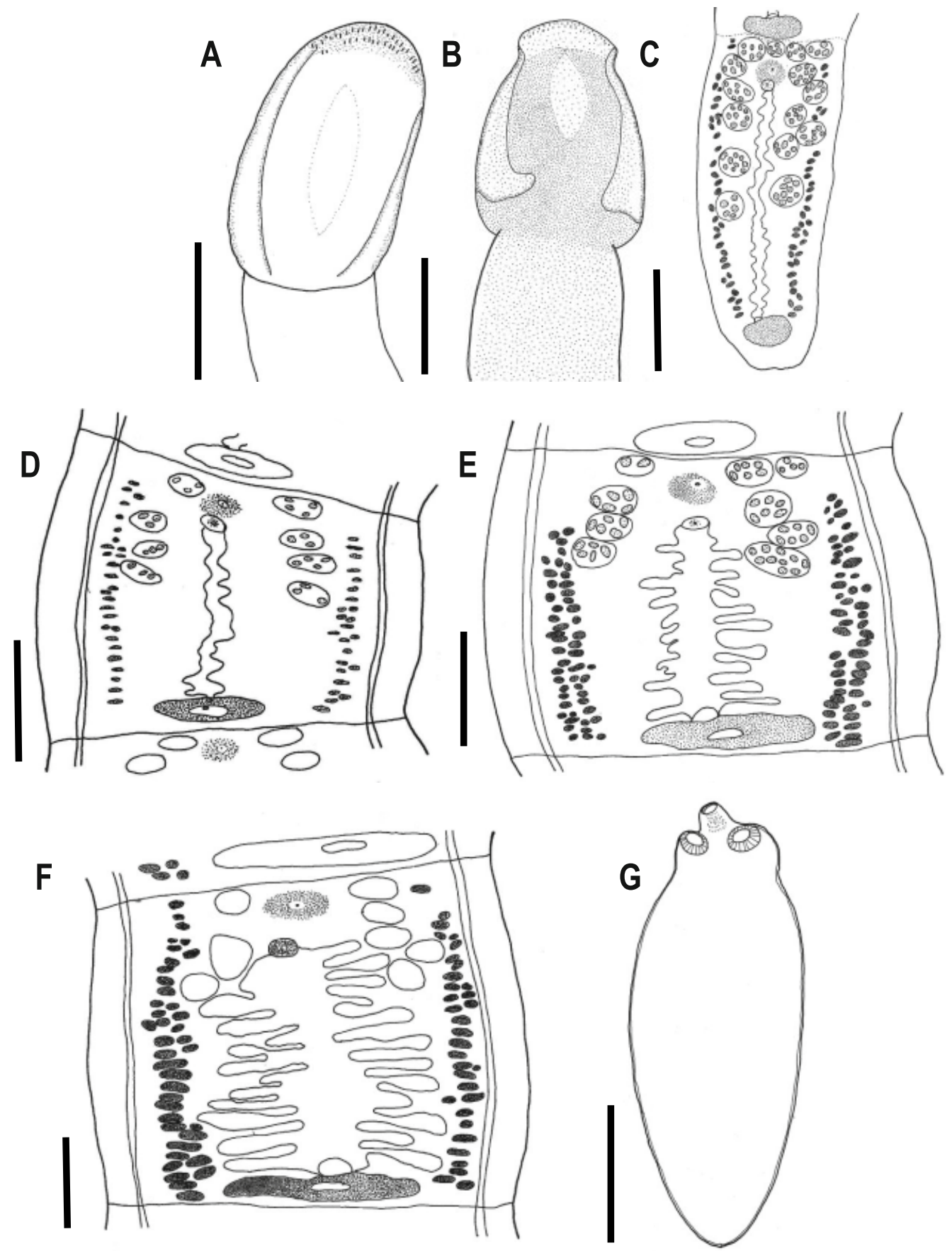

Fig. 2. Some cestodes infecting anurans at Ase creek. Figs. A-F - Cephalochlamys compactus infecting H. occipitalis. A,B, scoleces (different specimens); C, D - mature proglottid (different specimens); E,F - gravid proglottids; $G$ - Larva of Proteocephalus sp. infecting H. galamensis. Scale bar: A,C-F $=0.30 \mathrm{~mm} ; B, G=0.2 \mathrm{~mm}$.

accession numbers are as follows: Cephalochlamys compactus (2016.12.8.1-3); Proteocephalus sp. larva (2016.12.8.4); Proteocephalid larvae (2016.12.8.5); Polystoma aeschlimanni (2016.12.8.8-9); Polystoma baeri (2016.12.8.10-11); Polystoma pricei (2016.12.8.12-13); Diplodiscus fischthalicus (2016.12.8.1415); Ganeo africana (2016.12.8.16-17); Metahaematoloechus exoterorchis (2016.12.8.18); Metahaematoloechus micrurus
(2016.12.8.19); Mesocoelium monodi (2016.12.8.20-21); strigeoid trematode larva (2016.12.8.22-23); Progonimodiscus colubrifer (2016.12.8.24-25); Batrachocamalanus siluranae (2016.12.8.2835); Oswaldocruzia hoepplii (2016.12.8.36-50) brachylaimid (Postharmostomum) metacercariae (2016.12.8.51-60); Amplicaecum sp. (2016.12.8.61-66; Foleyellides sp. I (2016.12.8.67-77 and Foleyellides sp. II (2016.12.8.78-97). 


\section{Results}

In this study, 125 anurans belonging to 13 taxa were examined: Afrixalus fulvovittatus (01), Sclerophys maculata (02), S. regularis (01), Hoplobatrachus occipitalis (05), Hylarana galamensis
(44), Hymenochirus sp. (06), Hyperolius fusciventris (01), Hyperolius fusciventris burtoni (07), Hyperolius concolor, phase B (16),

Ptychadena bibroni (23), P. mascareniensis (11), P. oxyrynchus

(10) and $P$. pumilio (05), with an overall parasite prevalence of $77.6 \%$.
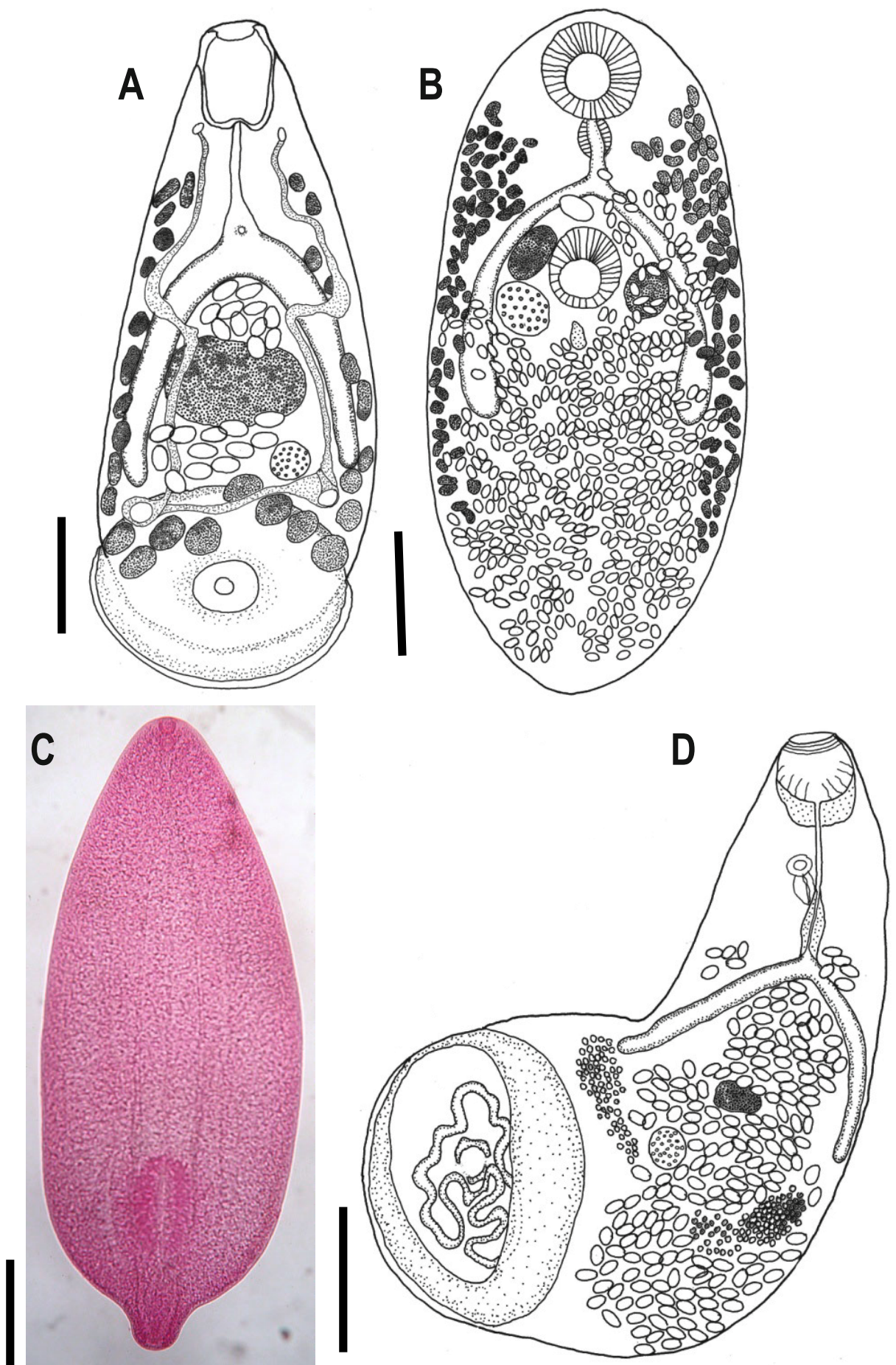

Fig. 3. Some digenetic trematodes infecting anurans from Ase creek.

A - D. fischthalicus; B - Mesocoelium sp.; C - Larval strigeoid; D - P. colubrifer. Scale bar: A, D $=0.5 \mathrm{~mm} ; \mathrm{B}, \mathrm{C}=0.25 \mathrm{~mm}$. 


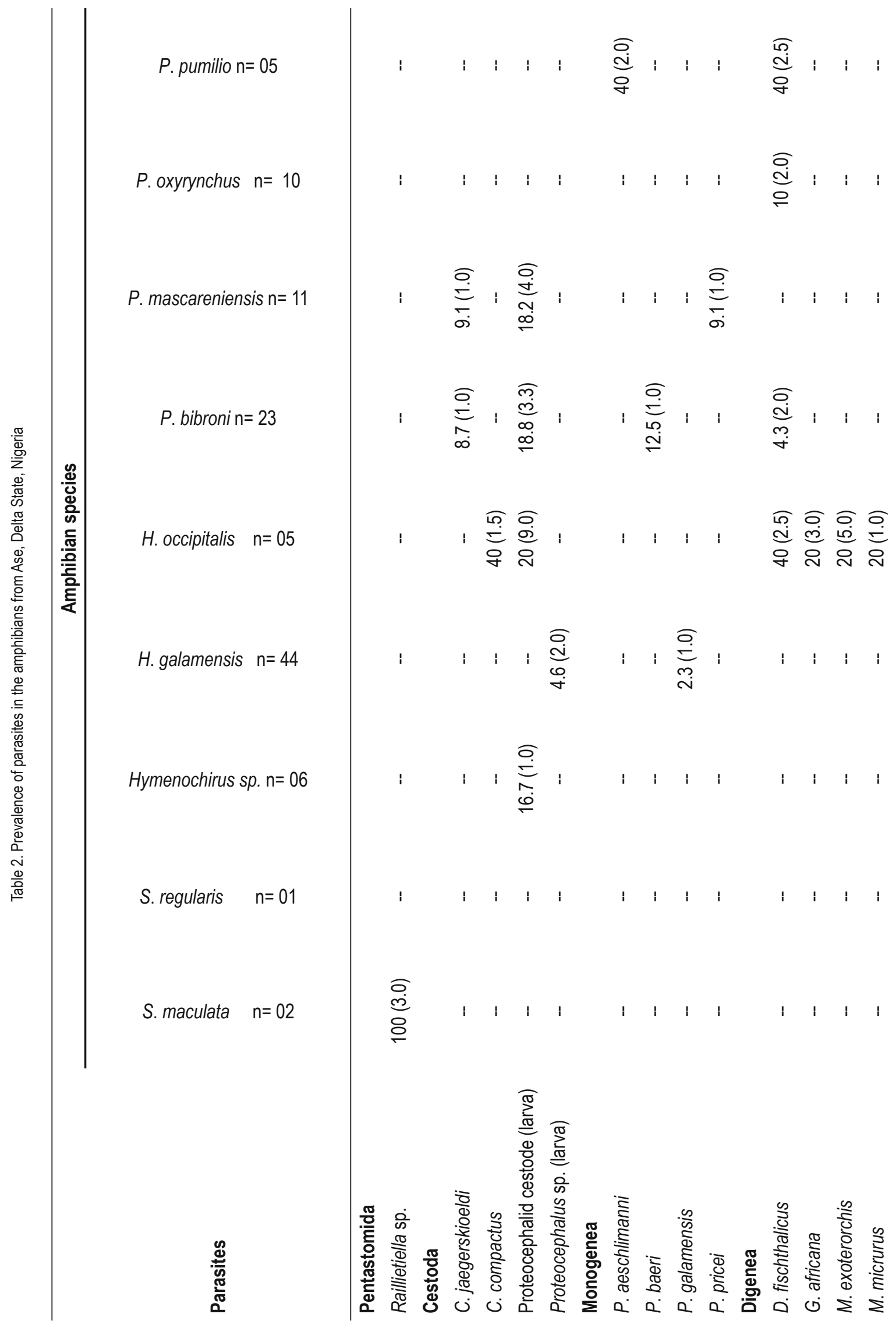




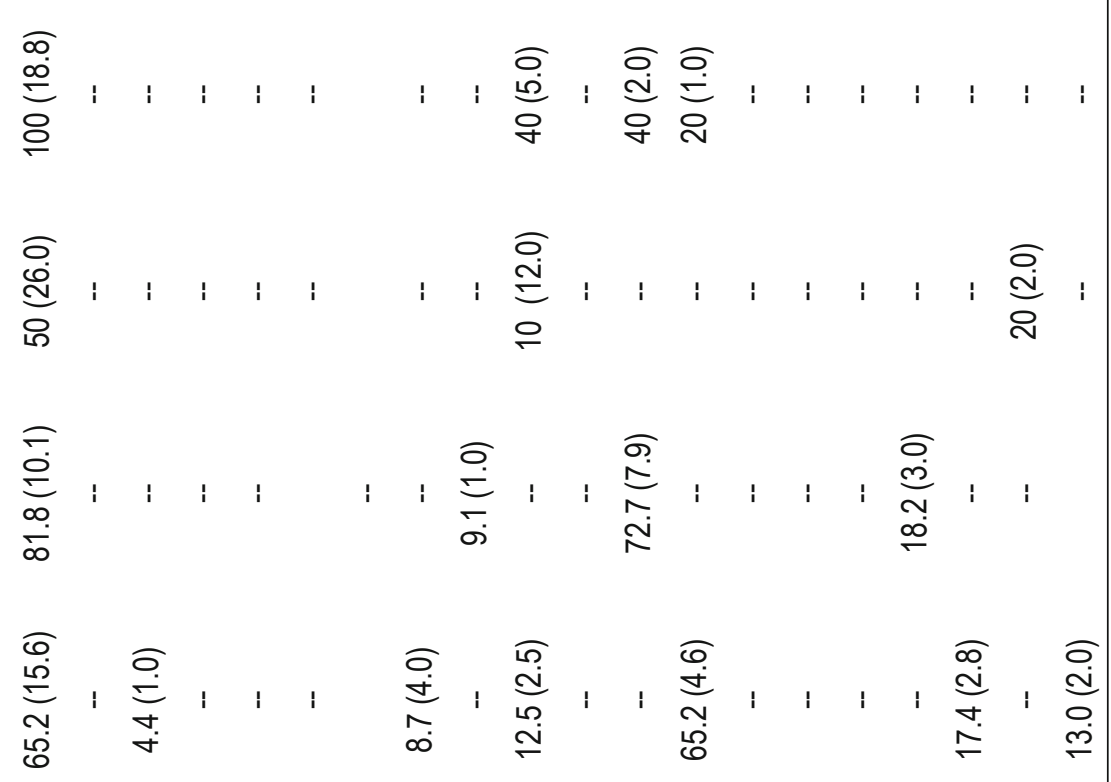

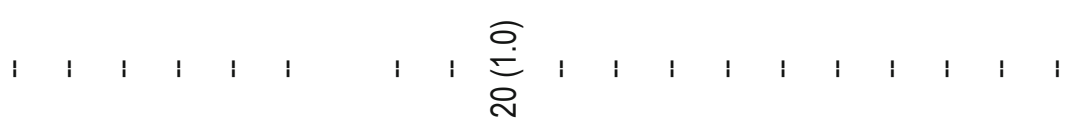

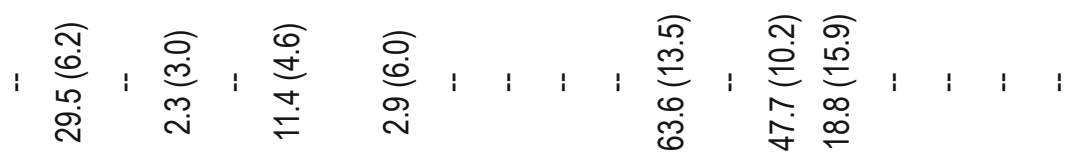

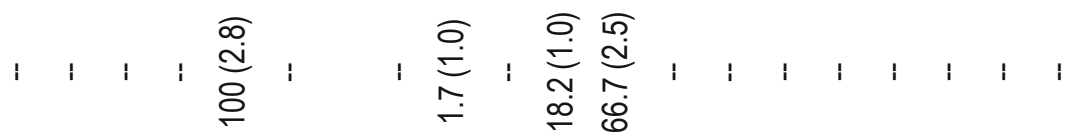

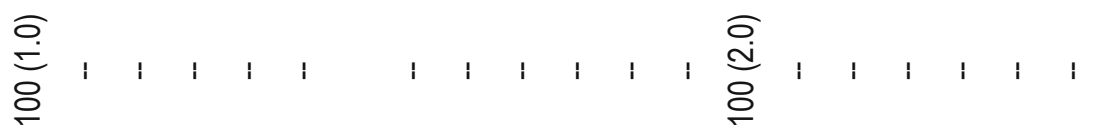

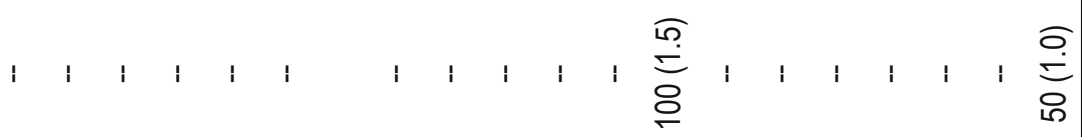

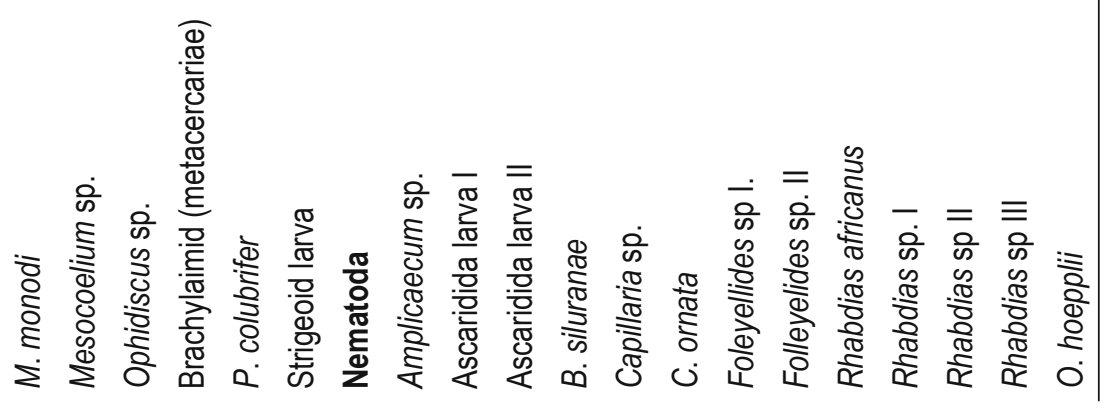



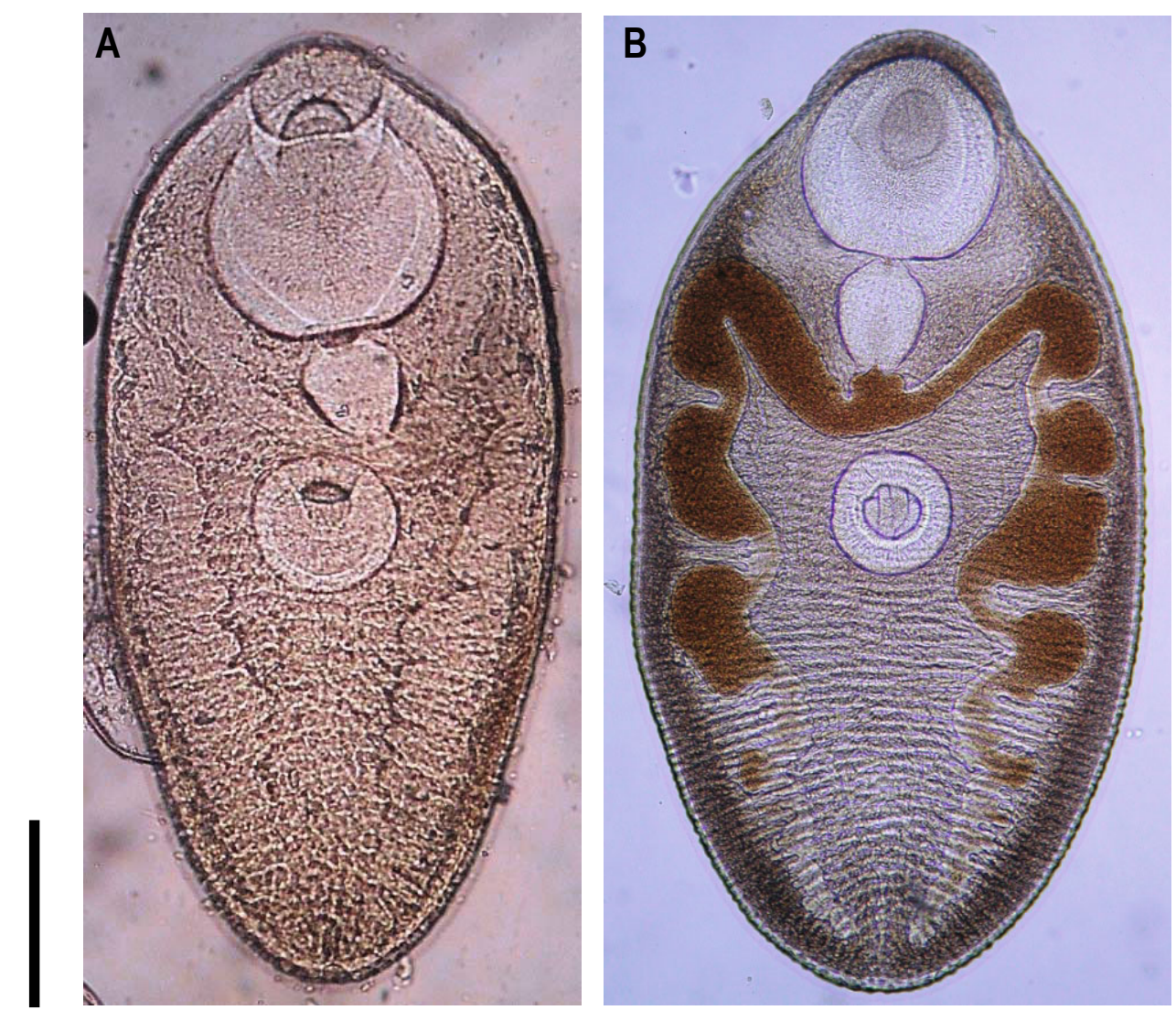

Fig. 4. Metacercariae of the brachylaimid trematode recovered from A - H. galamensi; B - L. aurora. Scale bar: $0.2 \mathrm{~mm}$

A total of 32 parasites were recovered and they consisted of one pentastomid; four cestode, four monogenean, 10 digenean and 13 nematode species. The sites of infection in the hosts are presented in Table 1. The prevalence and mean intensities (in parentheses) of the parasites recovered and the hosts from which they were recovered are presented in Table 2. No parasites were recorded in $H$. fusciventris burtoni; $P$. bibroni harboured 11 parasite species, followed by $H$. galamensis (9) and $P$. mascareniensis (8). The remaining frogs harboured between two and six parasite species (Table 2). A majority of the parasites parasitized only a single host, but some others including $C$. jaegerskioeldi, the proteocephalid cestode larva, D. fischthalicus, M. monodi, Amplicaecum sp., ascaridida larvae I and II, Capillaria sp., C. ornata, and O. hoeppli were generalist parasites, infecting between two and five different amphibian hosts (Table 2). Most of the parasites (26) were represented by adult stages while only six occurred as larvae and these included cestoda: (larval proteocephalid and Proteocephalus sp.); digenea (Brachylaimid metacercariae and the strigeoid larva); nematoda (ascaridida larvae I and II). The most parasitized habitat was the small intestine, followed by the lungs and the large intestine/rectum.

The pentastomid recovered was a Raillietiella sp., while the ces- todes included C. compactus (Fig. 2A - F) Proteocephalus sp. (Fig. 2G), C. jaegerskioeldi and cyst of a proteocephalid, which was a generalist parasite. Four Polystoma spp. infecting four different anuran hosts, all with low prevalence and intensity were recorded (Table 2). Ten digenetic trematodes, some of which include $D$. fischthalicus (Fig. 3A), an undetermined Mesocoelium sp. (Fig. 3B), a larval strigeoid (Fig. 3C), P. colubrifer (Fig. 3D) and a brachylaimid trematode metacercaria (Figs. $4 \mathrm{~A}$ - B) were recovered. Nematode parasites formed the largest group encountered, notably two larval ascaridida, one of which was encysted in the body cavity of Hymenochirus sp. and the second (Fig. 5A - D) embedded in the stomach mucosa of three anuran hosts (Table 2). Two species of Foleyellides were also observed to infect anurans in the study area; one occurring in the body cavity of $\mathrm{H}$. concolor (prevalence $25 \%$; mean intensity, 5.3), in the single specimen of A. fulvovittatus examined and $S$. regularis (Fig. $6 \mathrm{~A}-\mathrm{B}$ ) and the other in H. galamensis (Fig. 6C - D).

\section{Discussion}

The anuran species encountered during this study were rather few in view of the fact that Ase community is a humid freshwater envi- 

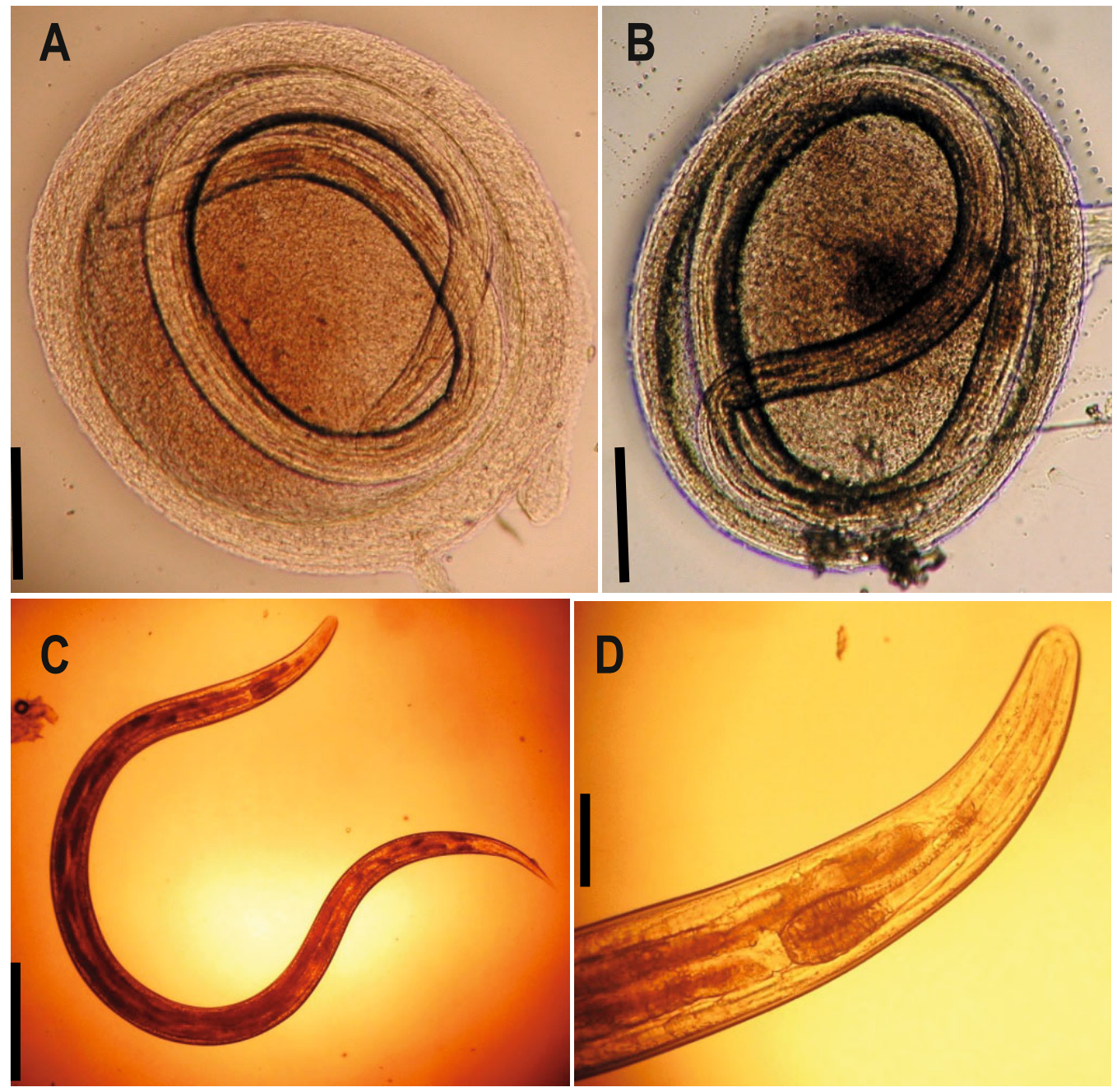

Fig. 5. Encysted larval ascaridida infecting anurans from the Ase creek. A,B - encysted larval (whole worm); $C$ - excysted larva; D - anterior end of excysted larva. Scale bar: $A, B=0.3 \mathrm{~mm} ; C=0.5 \mathrm{~mm} ; D=1 \mathrm{~mm}$

ronment, which should support a rich amphibian species diversity. The dominant species in this location was $H$. galamensis which was frequently encountered especially close to the water front. Ptychadena spp. were encountered inland near water puddles while the few $H$. occipitalis were caught near dug out fish ponds not far from human dwellings. This frog was hard to find because it is hunted and consumed by the locals. Among the tree frogs, Hyperolius concolor (phase B) was the most common, occurring among shrubs and fence hedges in the community.

Although as many as 32 parasites species were recorded in the anurans investigated, the following have previous records in $\mathrm{Ni}$ gerian amphibians; pentastomida: Raillietiella sp. in bufonids; cestoda: C. jaegerskioeldi, cysts of a proteocephalid and C. compactus; monogenea: $P$. aeschlimanni, $P$. baeri, $P$. galamensis and $P$. pricei; digenea: $D$. fischthalicus, $G$. africana, M. exoterorchis, M. micrurus, M. monodi and Ophidiscus sp.; nematoda: Ampli- caecum sp., B. siluranae, C. ornata; Foleyellides spp., O. hoepplli and the larval ascaridida I (Aisien et al., 2001, 2003, 2004a, 2009; Jackson and Tinsley, 2001; Oddo, 2008; Imasuen, 2010; Imasuen et al., 2012a). Nevertheless, C. compactus is of interest, being a generalist parasite, infecting pipid anurans in the rainforest and savannah-mosaic (Aisien et al., 2003; Imasuen and Aisien, 2015) and $H$. occipitalis in the Niger Delta region as earlier reported by Aisien et al. (2001) and recorded in the present study. While the juveniles of Proteocephalus sp. recovered from $H$. galamensis represent a new geographical record for Nigeria, this cestode has been reported elsewhere by other investigators (Goldberg et al., 2001; McKenzie, 2007). Until now, Polystoma galamensis was thought to be restricted to frogs from the savannah biotope (Aisien et al., 2004b) but its finding in Ase, albeit in very low prevalence changes the ecological restriction earlier ascribed to this parasite. Up to now we have not recorded the co-occurrence of $M$. exoteror- 

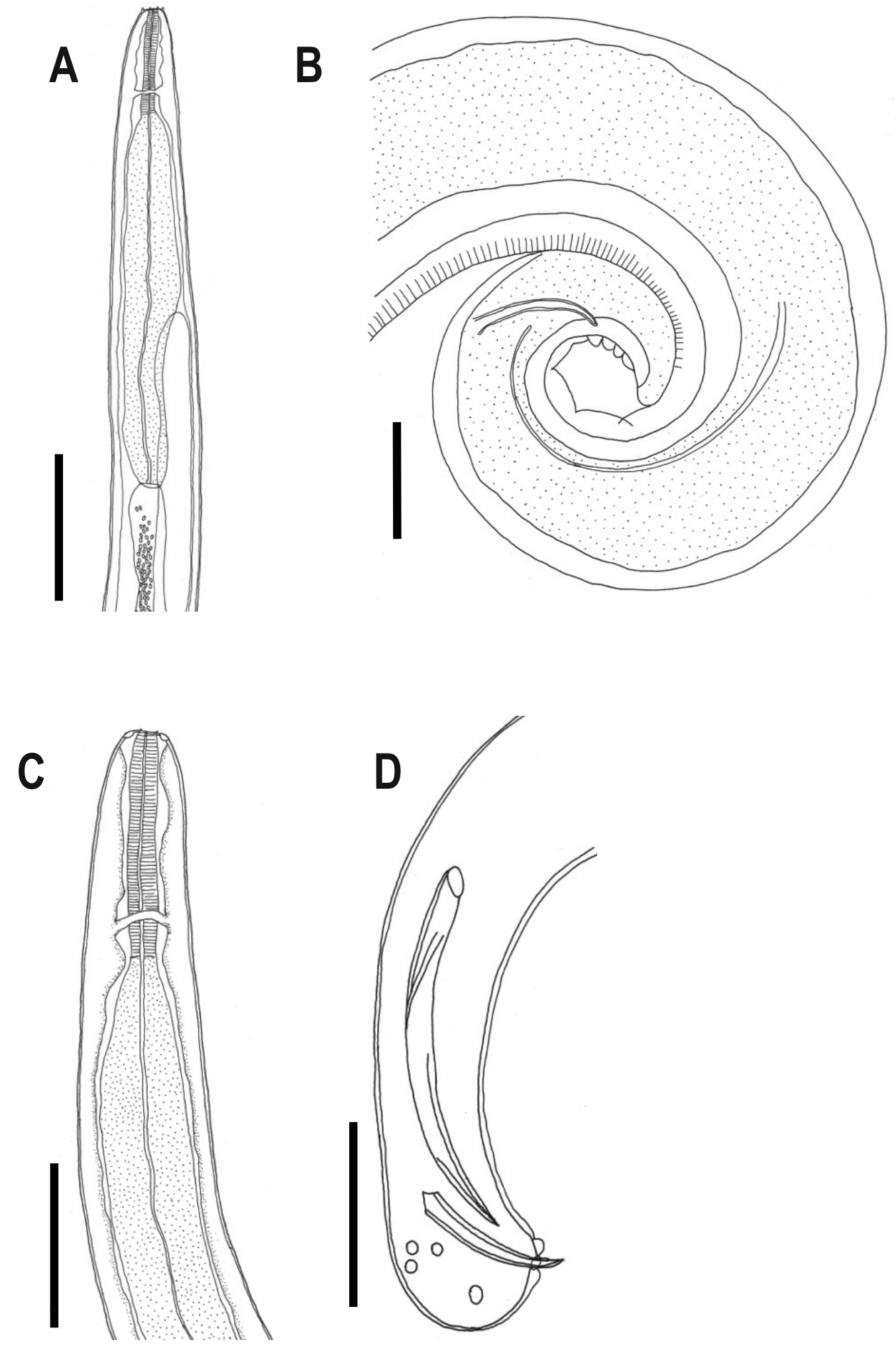

Fig. 6. Foleyellides spp. infecting anurans at Ase Creek. A-Anterior; B - posterior end of the species occurring in S. regularis and Hyperolius concolor, C - anterior end; $D$ - posterior end of the species occurring in $H$. galamensis. Scale bar: $A, B=0.1 \mathrm{~mm} ; C, D=0.3 \mathrm{~mm}$. 
chis and M. micrurus in the same host in Nigeria. The two species have always occurred separately in the infected hosts (Aisien et al., 2001, 2003, 2004a). Fischthal and Thomas (1968) had reported their co-occurrence in frogs examined in Ghana, which we also now observe in Nigeria. Mesocoelium sp. (Fig. 3B), which is different from M. monodi both in size and morphological characteristics was found in $H$. galamensis. The parasite had a mean length of $1.01 \mathrm{~mm}(0.67-1.40 \mathrm{~mm})$ and was $0.56 \mathrm{~mm}(0.44-0.78 \mathrm{~mm})$ in diameter. Although the parasite has some resemblance of $M$. cameroonensis by the short length of the intestinal caeca, it however differs from this parasite in some respect: the testes are slightly smaller than the ovary, contrary to what is observed in M. cameroonensis; the vitellaria extend to the posterior third of the parasite beyond what is described for M. cameroonensis (see Saoud, 1964; Dronen et al., 2012).

One interesting finding in this study was the recovery of the metacercariae of a brachylaimid trematode from the rectum of $H$. galamensis. Members of the Brachylaimidae are parasitic mostly in domestic and wild birds as well as in some small mammals (Alicata, 1940; Ulmer, 1951a, b; Sirgel et al., 2012) and use terrestrial gastropods as first and second intermediate hosts. The only brachylaimid trematode known so far to have an amphibian definitive host is Zeylanurotrema spearei, which is parasitic in the urinary bladder of Bufo marinus (see Cribb and Barton, 1991). We have recovered metacercariae identical to the ones we recovered from $H$. galamensis in the snail, Limicolaria aurora. Since no further development of this parasite occurred in $\mathrm{H}$. galamensis, this frog is most likely an accidental host, which probably acquired the parasite from the consumption of an infected snail or vegetation contaminated with shed metacercariae. Awharitoma et al. (2003) found the metacercariae of Brachylaima fuscatum in the snail $L$. aurora. Adults of this parasite were recovered from domestic chicks infected by cloacal drop (Herman and Bacha, 1978), 29 days post-infection. In view of the close similarity among the metacercariae of brachylaimids, it needs to be experimentally determined if the metacercariae recovered from $L$. aurora and $H$. galamensis are those $B$. fuscatum or some other member of the Bracylaimidae. This clarification is necessary, because, another brachylaimid trematode (Postharmostomum ntowi) is known to infected domestic chicken in Ghana (Hodasi, 1969).

Progonimodiscus colubrifer appears to be a common parasite of pipid anurans as this parasite also infects Xenopus tropicalis collected from the Lagos area of Nigeria (Jackson and Tinsley, 1998b). Hymenochirus sp. is therefore a new host record for the parasite. Hylarana galamensis is also a new host record for the strigeoid metacercaria previously reported in $A$. dorsalis by Edo-Taiwo et al. (2014). According to Niewiadomska (2002), trematodes with this metacercarial type include Diplostomum, Neodiplostomum and Alaria spp., and they presumably use these frogs as intermediate hosts.

Among the nematodes, two Foleyellides species infect anurans in Ase community. One species is a generalist parasite, infecting two tree frogs and $S$. regularis. Infection with this species occurs in S. regularis in the savannah-mosaic (Aisien et al., 2003) and in $H$. fusciventris burtoni from the Okomu National Park (Imasuen et al., 2012a), while the second which is restricted to $H$. galamensis infects the same host in the savannah-mosaic (Aisien et al., 2003). The high prevalence and intensity of infection recorded for this parasite (47.7\%/10.2 worms per infect host) bears direct relationship with the high population density of mosquitoes in the locality. This observation is in agreement with Anderson (2000), who had incriminated haematophagus insects in the transmission of these parasites. In addition to $R$. africanus (Kuzmin, 2001), which infects bufonids there are other undetermined Rhabdias spp. infecting Ptychadena spp. in Ase community and other locations in southern Nigeria (M.S.O. Aisien, unpublished observations). There is a need to establish the identities of these other members of the Rhabdiasidae infecting Nigerian amphibians. The finding of a Capillaria sp. in $P$. mascareniensis and $P$. pumilio increases the host range for the parasite in Nigerian amphibians. A previous record of this parasite was made by Thurston (1970), who reported the presence of this parasite in the intestine Xenopus muelleri. Another vertebrate host harbouring Capillaria sp. in Nigeria is the lizard Agama agama reported by Adeoye and Ogunbanwo (2007). As already reported by Imasuen et al. (2012b), the larval ascaridida found in this study, whether in the body cavity or in the stomach mucosa, most probably use the infected anurans as transport hosts.

In conclusion, our study of the parasitic infections of anurans in Ase community reveals an interesting biotope with a low amphibian diversity whose members habour a rich community of parasites. From the 125 specimens (spread across 13 species) examined, 32 parasite species representing three helminth Phyla were recorded. The digenea and nematoda were the predominant groups represented by 10 and 13 species, respectively. Parasites recovered exhibited different life cycle patterns. While parasites like the monogeneans have a direct life cycle, others including the filariids are transmitted by arthropod (mosquitoes) vectors, others use the anurans either as intermediate or paratenic hosts.

\section{Acknowledgements}

We are grateful to Engineer Henry Ugbomeh, who facilitated our trips to Ase and to Mr. Festus Arijode for his technical assistance during the field collections.

\section{References}

Adeoye, G.O., Ogunbanwo, O.O. (2007): Helminth parasites of the African lizard Agama agama (Squamata: Agamidae). Rev. Biol. Trop., 55(2): $417-425$.

Aisien, S.O., Ugbo, A.D., Ilavbare, A.N., Ogunbor, O. (2001): Endoparasites of amphibians from south-western Nigeria. Acta Parasitol., 46 (4): 299 - 305 
Aisien, S.O., Ajakaiye, F.B., Braimoh, K. (2003): Helminth parasites of anurans from the savannah-mosaic zone of south-western $\mathrm{Ni}$ geria. Acta Parasitol., 48(1): 47 - 54

Aisien, S.O., AyenI, E., ILECHIE, I. (2004a): Helminth fauna of anurans from the Guinea savanna at New Bussa, Nigeria. Afr. Zool., 39 (1): $133-136$

Aisien, S.O., Salami, L.A., Obaro, F.E., Erakpoweri, S.O. (2004b): The influence of climate on the distribution of monogeneans of anurans in Nigeria. J. Helminthol., 78: 101 - 104. DOI: 10.1079/ $\mathrm{JOH} 2003227$

Aisien, M.S.O., Du Preez, L.H. (2009): A re-description of Polystoma africanum Szidat 1932 (Monogenea: Polystomatidae). Zootaxa, 2095: 37 - 46

Aisien, M.S.O., Ogoannah S.O., Imasuen, A.A. (2009): Helminth parasites of amphibians from a rainforest reserve in south-western Nigeria. Afr. Zool., 44(1): 1 - 7. DOI: 10.3377/004.046.0213

Aisien, M.S.O., Du Preez, L.H., Imasuen, A.A. (2011): Polystoma okomuensis n.sp. (Monogenea:Polystomatidae) from Boulenger's stripped frog Phlyctimantis boulengeri (Peret (1986) in Nigeria. J. Helminthol., 85(2): 153 - 159. DOI: 10.1017/ S0049x10000386221. Aisien, M.S.O., Aigbirior, P.O., Ovwah, E., Edo-Taimo, O. (2015): Blood parasites of some anurans from Edo State, Nigeria. Trop. Biomed., 32(4): 598 - 607

ALICATA, J.E. (1940): The life cycle of Postharmostomum gallinum, the caecal fluke of poultry. J. Parasitol., 26(2): 135 - 143. DOI: $10.2307 / 3272380$

Anderson, R.C. (2000). Nematode parasites of Vertebrates: their development and transmission, Second Edition. CABI Publishing, CAB International, Wallingford, Oxon OX10 8DE, U.K.

AverY, R.A. (1971): A preliminary list of parasites collected from reptiles and amphibians in Northern Nigeria. Brit. J. Herpetol., 4: $217-219$

Awharitoma, A.O., OKaKa C.E., Obaze, S.E. (2003): Larval stages of Brachylaima fuscatum in the terrestrial snail Limicolaria aurora from southern Nigeria. J. Helminthol., 77: 1 - 5. DOI: 10.1079/ JOH2002155

CRIBB, T.H., BARTON, D.P. (1991): Zeylanurotrerna spearei sp.n. (Digenea: Brachylaimidae) from the cane toad, Bufo marinus, in Australia. Zool. Scr., 20 (3): 207 - 213. DOI: 10.1111/j.14636409.1991.tb00286.x

CRUMP, M., Scott JR, N. (1994). Visual encounters surveys. In: W. Heyer, M. Donnelly, R. McDiarmid, L. Hayek, M. Foster (Eds) Measuring and monitoring biological diversity - standard methods for amphibians. Smithsonian Institution Press, ISBN-10 1560982845 , Washington, United States of America

Dronen, N.O., Calhoun, D.M., Simcik, S.R. (2012): Mesocoelium Odhner, 1901 (Digenea: Mesocoelidae) revisited; a revision of the family and re-evaluation of species composition in the genus. Zootaxa, 3387: 1 - 96

Edo-Taimo, O., Ovwah, E., Imasuen, A.A., Aisien, M.S.O. (2014): Larval strigeoid trematodes in anurans from southern Nigeria. Helminthologia, 51 (4): 318 - 322. DOI:10.2478/s11687-014-0247-2
Fischthal, J.H. Thomas, J.D. (1968): Digenetic trematodes of amphibians and reptiles from Ghana. Proc. Helminthol. Soc. Wash., 35(1): 1 - 15

Goldberg, S.R., Bursey, C.R., Mckinnell, R.G., TAN, I.S. (2001): Helminths of northern Leopard frogs, Rana pipiens (Ranidae) from North Dakota and South Dakota. West. N. Am. Nat., 61(2): 248 251

HeRman, S.M., BaCHA, W.J. (1978): Growth, development, and site location of the trematode Himasthla quissetensis in the chick following cloacal drop infections with cercariae. J. Parasitol., 6(4): $827-830$

HoDASI, J.K.M. (1969): Comparative studies on the helminth fauna of native and introduced domestic fowls in Ghana. J. Helminthol., 43: 35 - 52. DOI: 10.1017/S0022149X00003904

IMASUEN, A.A. (2010): Investigations of the helminth parasitic infections and chytridiomycosis of amphibians in Okomu National Park, Nigeria. Ph.D. Thesis, University of Benin, Benin City, Nigeria IMASUEN, A.A., AISIEN, M.S.O. (2012). Digenetic trematodes parasitic in anurans from rainforest biotopes in Edo State, Nigeria. The Zoologist, 10, 25 - 33

IMASUEN, A.A., AISIEN, M.S.O. (2015): Helminth parasites of Silurana tropicalis from the Okomu National Park, Edo State, Nigeria. Nigerian Journal of Parasitology, 36(1): 61 - 66.

Imasuen, A.A., Enabulele, E.E., Aisien, M.S.O. (2012a): Helminth community of tree frogs at the Okomu National Park, Edo State, Nigeria. Nigerian J. Parasitol., 33(1): 1 - 8

ImAsuen, A.A., Ozemoka, H.J., Aisien, M.S.O. (2012b): Anurans as intermediate and paratenic hosts of helminth infections in the rainforest and derived savannah biotopes of southern Nigeria. Int. J. Zool., Article ID 82370, 7 pages. DOI: 10.1155/2012/82370

JACKSON, J.A., TINSLEY, R.C. (1995): Representatives of Batrachocamallanus n. g. (Nematoda: Procamallaninae) from Xenopus spp. (Anura: Pipidae): geographical distribution, host range and evolutionary relationships. Syst. Parasitol., 31: 159 - 188. DOI: 10.1007/BF00009115

JACKSON, J.A., TINSLEY, R.C. (1998a): Hymenochirine anurans (Pipidae) as transport hosts in camallanid nematode life-cycles. Syst. Parasitol., 39: 141 - 151. DOI: 10.1023/A:1005978429651

JACKSON, J.A., TINSLEY, R.C. (1998b): Paramphistome digeneans from Xenopus species (Pipidae) in Africa: taxonomy, host specificity and biogeography. Syst. Parasitol., 40: 143 - 160. DOI: 10.1023/A:1005936429562

JACKSON, J.A., TINSLEY, R.C. (2001): Host specificity and distribution of cephalochlamydid cestodes: correlation with allopolyploid evolution of pipid anuran hosts. J. Zool. (Lond.), 254: 405 - 419. DOI: 10.1017/S0952836901000905

KhalIL, L.F., Jones A., BRAY R.A. (1994): Keys to the cestode parasites of vertebrates $\mathrm{CAB}$ International, Wallingford, $751 \mathrm{pp}$.

Kuzmin, Y. (2001): Rhabdias africanus sp. nov. (Nematoda, Rhabdiasidae), a new nematode species from South African toads (Amphibia, Bufonidae). Acta Parasitol., 46 (2): 148 - 150

McKenZIE, V.J. (2007). Human land use and patterns of parasitism 
in tropical amphibian hosts. Biol. Cons., 137: 12 - 116. DOI:1016/j. biocon.2007.01.019

NiEWIADOMSKA, K. (2002): The Superfamily Diplostomoidae Poirier, 1886. In: Gibson, D.I., Jones, A., Bray, R.I. (Eds), Keys to the Trematoda Vol1. London, U.K: CABI Publishing and the Natural History Museum, pp. 159 - 166

Oddo, U.O. (2008): Helminth parasites of amphibians from the freshwater swamp at Sapele, Delta State, Nigeria. B.Sc. Dissertation, University of Benin, Benin City, Nigeria

Prudhoe, S., Bray, A. (1982): Platyhelminth parasites of the Amphibia. British Museum (Natural History), Oxford University Press, London

Roedel, M.-O. (2000). Herpetofauna of West Africa Vol. 1. Amphibians of the West African Savanna. Edition Chimaira, Frankfurt, pp. 332

SAOUd, M.F.A. (1964): On some digenetic trematodes (Mesocoelium spp.) from Amphibia and Reptilia of the Cameroons. J.Helminthol., 38: 291 - 302. DOI: 10.1017/S0022149X00033861

ScHıøZ, A. (1963). The amphibians of Nigeria. VidenskabeligeMeddelelser fra Dansk Naturhistorisk Forening 125, 1 - 92

ScHıøт, A. (1967). The treefrogs (Rhacophoridae) of West Africa. Spolia zoologica Musei Haunienses 25, 1 - 346
ScHıøZ, A. (1999). Treefrogs of Africa. Edition Chimaira, Frankfurt, pp. 350

SiRgel, W.F., Artigas, P., Barques, M.D., Mas-Coma, S. (2012): Life cycle of Renylaima capensis, a brachylaimid trematode of shrews and slugs in South Africa: two host and three host transmission modalities suggested by epizootiology and DNA sequencing. Parasit. Vectors, 5: 169. DOI: 10:1186/1756-3305-169

ThuRston, J.P. (1967): The morphology and life-cycle of Cephalochlamys namaquensis (Cohn, 1906) (Cestoda: Pseudophyllidea) from Xenopus muelleri and $X$. laevis. Parasitology, 57: 187 - 200. DOI: 10.1017/S0031182000072000

ThURSTON, J.P. (1970): Studies on some protozoans and helminth parasites of Xenopus, the African clawed toad. Rev. Zool. Bot. Afr., 82: $349-369$

ULmeR, M.J. (1951a): Postharmostomum helicis (Leidy, 1847) Robinson, 1949, (Trematoda), its life history and revision of the subfamily Brachylaeminae. Part I. T. Am. Microsc. Soc., 70: 189- 238 Ulmer, M.J. (1951b): Postharmostomum helicis (Leidy, 1847) Robinson, 1949, (Trematoda), its life history and revision of the subfamily Brachylaeminae. Part II. T. Am. Microsc. Soc., 70: 319 - 347 YamaGuti S. (1971): Synopsis of digenetic trematodes of vertebrates. Vol. I. Keigaku Publ. Co., Tokyo 